\title{
Science survives Canadian budget
}

\section{Spending plans aim to battle national deficit yet still invest in research.}

While many nations are slashing science funding in austerity budgets, Canada's financial plan for the coming year defies the trend, leaving most scientists grudgingly happy with the results.

The federal budget for 2010-11, unveiled on 4 March, provides modest increases for the major science funding agencies, after a cut last year (see Nature 457, 646; 2009), and makes important investments in postdoc appointments. It means that Canada will probably keep its ranking as the top spender on science among the G7 leading industrialized countries, in terms of how much of its gross domestic product it invests in university research and development. The budget is seen by many as an attempt to placate a scientific community outraged by last year's cuts, and an acknowledgement of the importance of science to job creation.

The country's three main granting councils the Natural Sciences and Engineering Research Council of Canada (NSERC), the Canadian Institutes of Health Research and the Social Sciences and Humanities Research Council of Canada - together received a Can\$32-million (US\$31-million) annual boost. But that doesn't make up for last year's cut of Can $\$ 43$ million, and it leaves NSERC's annual billion-dollar budget relatively flat. "We're profoundly disappointed," says James Turk, executive director of the Canadian Association of University Teachers in Ottawa, Ontario. "In real dollar terms they're behind where they were last year."

Others see the results in a better light.

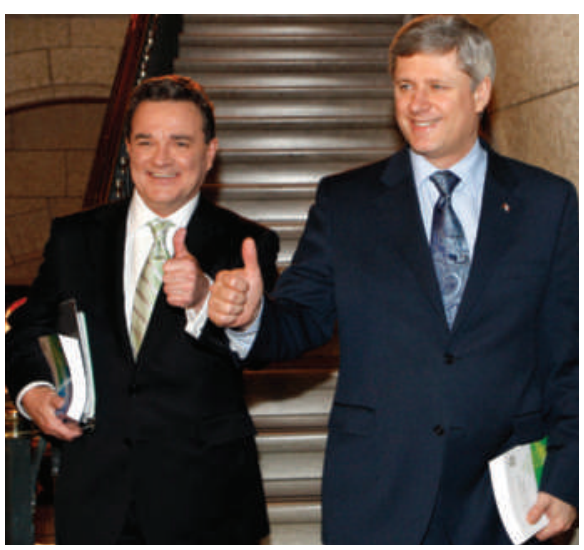

Finance minister Jim Flaherty and Prime Minister Stephen Harper give a thumbs up to science.

"When I look at the extent of restraint that the government has had to apply to manage a deficit, we are one of the only areas that has come out on top," says Indira Samarasekera, president of the University of Alberta in Edmonton. "I declare these increases as absolutely a victory."

The budget also creates a Can $\$ 45$-million competitive postdoc programme (see table), with a stipend of Can $\$ 70,000$ per year for 140 recipients. That might not sound like a lot of postdocs - it is about 10\% of the University of Toronto's allocation alone, says Turk - but the high pay means that the programme should be able to attract young stars from around the globe. "It allows us to go after absolutely the best," says Samarasekera.

\begin{tabular}{|c|c|c|}
\hline \multicolumn{3}{|c|}{ SCIENCE HIGHLIGHTS IN CANADA'S BUDGET } \\
\hline How much? & Who gets it? & What's it for? \\
\hline$\$ 45$ million over 5 years & The three main granting councils & Recruiting top-level postdocs \\
\hline$\$ 18$ million over 5 years & Indian and Northern Affairs Canada & $\begin{array}{l}\text { Design of the Canadian High Arctic } \\
\text { Research Station }\end{array}$ \\
\hline $\begin{array}{l}\$ 126 \text { million over } 5 \text { years } \\
\text { (plus } \$ 96 \text { million of } \\
\text { previously committed funds) }\end{array}$ & TRIUMF & $\begin{array}{l}\text { Running costs for this world-class } \\
\text { particle-physics research centre }\end{array}$ \\
\hline$\$ 75$-million lump sum & Genome Canada & $\begin{array}{l}\text { Ongoing support plus new funds for } \\
\text { forestry and environment research }\end{array}$ \\
\hline $\begin{array}{l}\$ 397 \text { million over } 5 \text { years } \\
\text { (plus } \$ 100 \text { million previously } \\
\text { committed) }\end{array}$ & Canadian Space Agency & $\begin{array}{l}\text { Development of the RADARSAT } \\
\text { constellation of Earth-monitoring } \\
\text { satellites }\end{array}$ \\
\hline$\$ 48$ million over 2 years & $\begin{array}{l}\text { Natural Resources Canada, } \\
\text { Canadian Institutes of Health } \\
\text { Research, Health Canada }\end{array}$ & $\begin{array}{l}\text { Developing better ways to make and } \\
\text { use medical isotopes }\end{array}$ \\
\hline$\$ 135$ million over 2 years & $\begin{array}{l}\text { National Research Council Canada } \\
\text { regional innovation clusters }\end{array}$ & $\begin{array}{l}\text { Promoting partnerships between } \\
\text { business, academia and government }\end{array}$ \\
\hline
\end{tabular}

HEAVY ANTIMATTER

Most massive antimatter nucleus yet identified in particle experiments.

go.nature.com/sC287v
TRIUMF, Canada's national laboratory for particle physics at the University of British Columbia in Vancouver, received the same amount in this budget as it did in its last five-year instalment, says director Nigel Lockyer. "Given the [financial] environment, we're extremely pleased with what we've got." The lab will have to cancel some projects, but it will still be able to focus on its two priorities: collecting data from the Large Hadron Collider at CERN, Europe's particle-physics centre in Geneva, Switzerland, and expanding its nuclear-medicine programme. TRIUMF also hopes to benefit from a new, Can\$48-million pot for technologies to replace Canada's troubled medical-isotopes facilities (see Nature 460, 312-313; 2009).

\section{Forestry focus}

On environmental issues, the budget builds on last year's Economic Action Plan (which included a billion dollars each for clean energy and green infrastructure) with, for example, Can $\$ 100$ million over four years to develop clean-energy production in the forestry sector. Genome Canada, which was neglected in last year's budget, has been given money specifically for forestry and environmental work.

One of the biggest winners is the Canadian Space Agency, with Can $\$ 397$ million to develop the RADARSAT constellation of three Earthmonitoring satellites planned for launch in 2014. Another Can\$18 million will go towards designing a promised High Arctic Research Station. The Canadian Foundation for Climate and Atmospheric Sciences was not so fortunate, however. Established by the federal government in 2000, the foundation has been pumping some Can $\$ 10$ million a year into climate research and outreach, roughly on a par with recent NSERC climate-science grants. But its funding has not been renewed, and its projects will now have to wind up over the coming year. "It is a very serious body blow to climate research in Canada," says Tom Pedersen, director of the Pacific Institute for Climate Solutions in Victoria, British Columbia.

The budget also announces plans for a comprehensive review of all federal support of research and development. A negative review could spell trouble for science, especially in light of further national belt tightening, says Paul Dufour, a science-policy expert with the International Development Research Centre in Ottawa, Ontario. "Next year and beyond we're going to really start to see the hit."

Nicola Jones 


\section{US health bill promises changes for biomedical researchers}

总

The historic health-care bill that passed the US House of Representatives on 21 March includes several lesser-known provisions that will significantly affect biomedical researchers, teaching hospitals and the biotechnology industry.

The final legislation, which is expected to become law, would establish a new competitive grant programme at the National Institutes of Health (NIH). Called the Cures Acceleration Network (CAN), this provision was written into the law by Senator Arlen Specter (Democrat, Pennsylvania). It will authorize as much as US $\$ 500$ million annually for speeding the translation of basic discoveries into treatments, through individual awards of up to \$15 million per year. The CAN would be separate from an already existing NIH programme called Clinical and Translational Science Awards, which has a budget of roughly $\$ 483$ million in 2010 .

The CAN programme comes without the guarantee of new money, and how it will be funded remains unclear. Advocates for basic research are worried that if Congress does not increase the NIH budget, funding might be pulled from its flagship, investigatorinitiated R01 awards.

"There has already been a long slide or stagnation in the funding of the gold standard: the R01," says Mark Lively, president of the Federation of American Societies for Experimental Biology in Bethesda, Maryland. "We would be concerned that any mandate that would require the NIH to move money to the $\mathrm{CAN}$ could very well come at the cost of losing still more R01s."

Another provision in the bill will expose relationships between physician researchers and the medical industry. From 2013, companies will have to report to the Department of Health and Human Services every payment in cash, stock or kind of more than $\$ 10$ they make to physicians and to teaching hospitals, in gifts, entertainment, and for services such as consulting and public speaking. The department will post the payments in a publicly accessible database.

Companies that produce biologics complicated and expensive protein-based drugs - do well out of the legislation. The new law will effectively guarantee

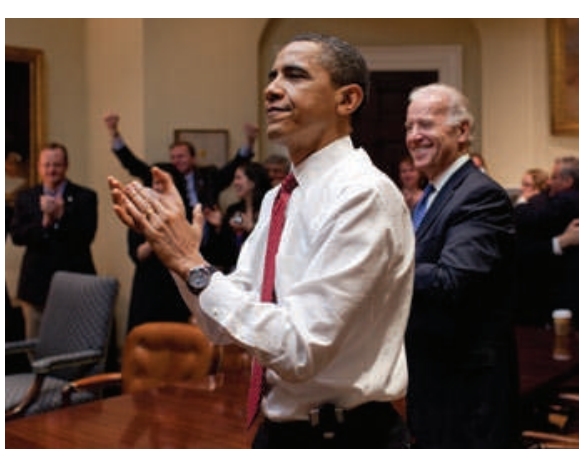

Barack Obama applauds the health reform bill.

12 years of exclusive market access for makers of brand-name biologics before generic competitors can produce 'biosimilars', which mimic the original molecules.

This provision is part of language that establishes a regulatory path by which makers of biosimilars can win marketing approval from the Food and Drug Administration (FDA). The European Union opened just such a regulatory path in 2005; the European Medicines Agency has since approved 14 such drugs.

When Congress considered similar biologics legislation in 2008, the Congressional Budget Office estimated that its provisions for FDA approval of biosimilars would save about $\$ 25$ billion over ten years by driving down prices of biologic drugs.

Jim Greenwood, the president and chief executive of the Biotechnology Industry Organization, a lobby group based in Washington DC, said that the law "will lead to new and improved treatments, cures and cost-savings for patients, while driving job growth in our industry".

But Kathleen Jaeger, president of the Generic Pharmaceutical Association, also based in Washington DC, lamented the pathway's "excessive and unprecedented market exclusivity protections for the brand industry". Generics makers and their congressional allies had sought to limit brand-name exclusivity to six years.

\section{Correction}

The News story 'Science survives Canadian budget' (Nature 464, 153; 2010) gave the wrong affiliation for Paul Dufour: he is head of the science-policy consultancy Paulicyworks based in Gatineau, Quebec. 